\title{
Who is Bakhtin?
}

\author{
E. Jayne White ${ }^{1}$
}

Published online: 18 June 2015

(C) Springer Science+Business Media Dordrecht 2015

Mikhail Bakhtin (1895-1975), whose theory of dialogism frames this issue, led a long life during which he traversed significant ideological movements in Russian history and overcame many personal and political challenges along the way. While Bakhtin remains a somewhat mysterious character who refuses to be fully 'known' (an idea he himself developed in his early writings), there are some biographical details that provide important clues due to the painstaking work of the Bakhtin Centre and Bakhtin's own students who recognised the potential of his work. This information provides a rich tapestry about Bakhtin's scholarship that spans a lifetime of philosophical thought, and it offers considerable scope for contemporary theorisation.

Born in the Russia Empire, in the town of Orel, south of Moscow, Bakhtin spent his childhood as part of a family of five children, in Vilnius and Odessa. At the age of 9 years, he became very ill with a bone infection that was to eventually cost him his leg when he was 42 years of age. His experience of suffering and his fundamental awareness of the body as central to human encounter were hallmarks of his later scholarship. This may also have drawn him to one of his primary literary inspirations-Fryodor Dostoevsky — who also pioneered the notion of polyphonic writing that Bakhtin so admired. Despite significant challenges, Bakhtin attended University in Odessa between 1913 and 1916 and subsequently studied philology (study of language) at University of Petrograd until 1918. There are no records to suggest that he ever officially graduated.

During this post-revolutionary period of his life, Bakhtin engaged with scholars, philosophers, dancers, poets, artists, and thinkers who have subsequently been

E. Jayne White

whiteej@waikato.ac.nz

1 University of Waikato, Private Bag 3105, Hamilton 3240, New Zealand 
named 'The Bakhtin Circle(s)'. These groups participated in public lectures, theatre, and frequent candlelit late night dialogues about their developing ideas-work described by Bakhtin himself as 'difficult and laborious ... revaluation and testing of all our previous knowledge and convictions" ${ }^{1}$ (cited in Hirschkop 1999, p. 147). The influence of these liaisons on Bakhtin's thinking cannot be overemphasised. In particular, his key ideas concerning answerability, ethics, and love can be traced back to this era; which was cut short due to Stalinist interventions in the late 1920s.

These political manoeuvres to shut down 'dangerous' dialogues amongst Russian intelligentsia saw several of Bakhtin's colleagues executed or, as in the case of Bakhtin himself, exiled. His exile lasted for 11 years in Kazakhstan where many of his writing projects evolved. Writings that were to underpin his books such as Problems of Doestoevsky's Poetics (Bakhtin 1984), Art and Answerability (Bakhtin 1990) were completed during this period, even though they were not actually published until many years later. Others, such as Marxism and the Philosophy of Language (Voloshinov 1973), were said to be written under Bakhtin's influence even though he never officially claimed authorship himself. This claim continues to be vehemently disputed even today. Regardless, the influence of these ideas is clearly evident in texts Bakhtin authored himself and, perhaps, lived out through his ideas concerning authorship as a dialogic event.

Returning to public life in 1940, Bakhtin began work on a thesis on laughter, which was to become one of his most important works, titled Rabelais and His World (1968). This work foregrounded another of Bakhtin's important contributions concerning carnivalesque, laughter, and the body. Eventually, after an initial rejection due to the radical nature of his ideas that were not welcomed in Russia during this Stalinist period, Bakhtin received a higher degree in 1951. His ideas were clearly not only before his time, but also considered inappropriate for the political era in which he was located.

Aside from his prolific writing activity, Bakhtin was also a teacher. He taught literature at the Moradavian State Pedagogical Institute in Saransk for many years. During this time, he produced several more papers and notes that were eventually collated into publications. Of note, is his one and only known pedagogical piece titled, Dialogic Origin and Dialogic Pedagogy of Grammar, only recently published in 2004, in which he introduces the importance of 'lively discussions' in the classroom as central to learning.

His final book, Speech Genres and Other Late Essays (Bakhtin 1986), collated from fragments after his death, outlines a methodological agenda for dialogic studies. It is a book that continues to inform and inspire many researchers today. Together with his corpus of books, notes, and memoirs, Bakhtin's legacy is now felt in many countries around the world and, more recently, in education (Matusov 2009; Wegerif 2013: White and Peters 2011). It is from here that this issue of the journal takes its cue by introducing a series of new and innovative studies that attempt to bring Bakhtin to bear on the early years. As readers will see, there is not

\footnotetext{
${ }^{1}$ Bakhtin, in KGB archive, Leningrad region, cited in Hirschkop (1999, p. 147).
} 
one way to 'apply' Bakhtin's thinking, but as Bakhtin (1981) suggested himself, we are all 'answerable' for our interpretations and what we do with them.

\section{References}

Bakhtin, M. M. (1968). Rabelais and his world (H. Iswolsky, Trans.). Cambridge, MA: Massachusetts Institute of Technology.

Bakhtin, M. M. (1981). The dialogic imagination: Four essays (M. M. Bakhtin \& M. Holquist, Eds., C. Emerson \& M. Holquist, Trans.). University of Texas, USA: University of Texas Press.

Bakhtin, M. M. (1984). Problems of Dostoevsky's poetics (C. Emerson, Trans.). Minneapolis: University of Minnesota Press.

Bakhtin, M. M. (1986). Speech genres \& other late essays (C. Emerson \& M. Holquist, Eds., V. W. McGee, Trans.). Austin, TX: University of Texas Press.

Bakhtin, M. M. (1990). Art and answerability. Austin, TX: University of Texas Press.

Bakhtin, M. M. (2004). Dialogic origin and dialogic pedagogy of grammar: Stylistics in teaching Russian language in secondary school. Journal of Russian and East European Psychology, 42(6), 12-49.

Hirschkop, K. (1999). Mikhail Bakhtin: An aesthetic for democracy. Oxford: Oxford University Press.

Matusov, E. (2009). Journey into dialogic pedagogy. Hauppauge, NY: Nova Science.

Voloshinov, V. (1973). Marxism and the philosophy of language (L. Matejka \& I. R. Titunik, Trans.). Cambridge, MA: Harvard University Press.

Wegerif, R. (2013). Dialogic: Education for the internet age. Abingdon: Routledge.

White, E. J., \& Peters, M. A. (2011). Bakhtinian pedagogy: Opportunities and challenges for research, policy and practice across the globe. New York: Peter Lang. 